\title{
Notes on the Contributors
}

Maurizio Passerin d'Entrèves is Senior Lecturer in the Department of Government at the University of Manchester. He is the author of Modernity, Justice and Community (Franco Angeli, 1990) and The Political Philosophy of Hannah Arendt (Routledge, 1994). He is co-editor of, among other works, Habermas and the Unfinished Project of Modernity (Polity Press, 1996) and Public and Private: Legal, Political and Philosophical Perspectives (Routledge, 2000).

Marek Kwiek is Associate Professor of Philosophy at Adam Mickiewicz University, Poznan, Poland. Visiting Professor at the Central European University, 1999-2000, he has published widely on Rorty, Lyotard and Foucault. His most recent work includes The Dilemmas of Identity: the Self-Image of the Philosopher in Postwar French Thought (1999, in Polish) and The University - Globalization - Central Europe (edited, forthcoming).

Patrick Lenta lectures in Jurisprudence at the University of Natal, Durban, and is finishing his $\mathrm{PhD}$ on law in post-apartheid South Africa.

Claus Offe teaches political science at Humboldt University, Berlin. He is the author of, among many other works, Disorganized Capitalism (MIT Press, 1985), Varieties of Transition: the East European and East German Experience (MIT Press, 1996), and Modernity and the State (Polity Press, 1996).

Shane O'Neill is a Reader in Politics at Queen's University, Belfast. He has published articles on normative political philosophy, critical social theory and ethno-national conflict. His books include Impartiality in Context: Grounding Justice in a Pluralist World (SUNY, 1997) and (as co-editor) Reconstituting Social Criticism: Political Morality in an Age of Scepticism (Macmillan \& St Martin's Press, 1999).

Gayatri Chakravorty Spivak is Avalon Foundation Professor in the Humanities, English and Comparative Literature at Columbia University. The most recent of her many publications include Red Thread (forthcoming from Harvard University Press) and A Critique of Postcolonial Reason: Toward a History of the Vanishing Present (Harvard University Press, 1999). 